\title{
Design and Synthetic Scheme of Water Dispersible Graphene Oxide-Coumarin Complex for Ultra-Sensitive Fluorescence Based Detection of Copper $\left(\mathrm{Cu}^{2+}\right)$ Ion in Aqueous Environment
}

\author{
Srijita Basumallick \\ Department of Nanoscience and Technology Center, University of Central Florida, Orlando, USA \\ Email: srijitabasumallick@gmail.com
}

Received 11 August 2014; revised 4 September 2014; accepted 8 October 2014

Copyright (C) 2014 by author and Scientific Research Publishing Inc.

This work is licensed under the Creative Commons Attribution International License (CC BY).

http://creativecommons.org/licenses/by/4.0/

(c) (i) Open Access

\begin{abstract}
Copper oxides and its salts are now widely used as pesticides to control fungal and bacterial diseases of field crops. Copper toxicity is often a major contributor of human health problems caused through accumulation of excess copper ions in various organs via drinking water, fruits and vegetables. So, detection and estimation of cupric ions in biological organs, drinking water, fruits and vegetables are extremely important. Recently, a fluorescence based sensor using coumarin dye (high quantum yield) has been proposed to detect micro-molar $\mathrm{Cu}^{++}$ion in biological organs. But major problem with coumarin dye is that it is insoluble in water and undergoes dye-dye aggregation in organic solvents. We proposed here a synthetic scheme of preparation of graphene oxide conjugated coumarin dye derivative which would be water dispersible and expected to be an ideal candidate for $\mathrm{Cu}^{2+}$ ion estimation in biological organs and drinking water.
\end{abstract}

\section{Keywords}

Copper Ion Estimation, Fluorescence Sensor, Graphene-Oxide, Coumarin

\section{Introduction}

Copper salts are extensively used as pesticides (i.e. fungicide/bactericides) to control fungal and bacterial diseases of field crops [1]. Global annual production of metallic copper and copper compounds reached 13.6 mil-

How to cite this paper: Basumallick, S. (2014) Design and Synthetic Scheme of Water Dispersible Graphene Oxide-Coumarin Complex for Ultra-Sensitive Fluorescence Based Detection of Copper $\left(\mathrm{Cu}^{2+}\right)$ lon in Aqueous Environment. Graphene, 3, 45-51. http://dx.doi.org/10.4236/graphene.2014.34007 
lion metric tons in 1979 [2] and it is projected that $\mathrm{Cu}$ production will continue to increase in the future. $\mathrm{Cu}$ is naturally found in uncontaminated water sediment at a background concentration level ranging from 0.8 to 50 $\mu \mathrm{g} \cdot \mathrm{g}^{-1}$ (on a sediment dry weight basis) [3] whereas $\mathrm{Cu}$ level in uncontaminated soil is estimated to be $\sim 30$ $\mu \mathrm{g} \cdot \mathrm{g}^{-1}$ [4]. Aggressive use of $\mathrm{Cu}$ pesticides in agricultural industry is responsible for the accumulation of $\mathrm{Cu}$ in soil. There is an increasing concern that soil bound $\mathrm{Cu}$ might leach out from the agricultural fields and contaminate nearby water bodies such as rivers and lakes, adversely affecting the lives of aquatic vertebrates such as fish and invertebrates organisms. It is evident that continuous release of $\mathrm{Cu}$ to the environment through human activity will only increase the $\mathrm{Cu}$ level in drinking water and it could potentially exceed the EPA-set drinking water $\mathrm{Cu}$ limit (currently the limit is $1.3 \mathrm{ppm}$ ).

Copper is an essential trace element present in animal and plant tissue. However, overdose of $\mathrm{Cu}^{++}$ion is toxic and harmful to human and plant species. The average concentration of copper in human blood is estimated to be in the range 15.7 - $23.6 \mu \mathrm{M}$. Cu bioaccumulation and its imbalance however can cause serious health problem. A number of organ damages including stomach, kidney, liver, and brain have been related to $\mathrm{Cu}$ imbalance. It is reported that brain metabolism process is regulated by $\mathrm{Cu}$ [5] [6]. A number of neurodegenerative diseases including Alzheimer are linked to disturbance in Cu mediated metabolism processes [5] [6]. Other diseases such as Aceruloplasminemia [7], Wilson's and Menki's syndrome has been also related to Cu imbalance.

There is certainly a strong need to develop sensitive probe for the detection of trace level of $\mathrm{Cu}$ in biological and environmental samples. Some of important applications of the proposed probe in the environment would include monitoring of i) residual $\mathrm{Cu}$ pesticides in the plant surface (leaves and stems and fruits), ii) agricultural soil samples and iii) $\mathrm{Cu}$ level in contaminated water.

\subsection{Current Cu Ions Detection Techniques}

Atomic Absorption Spectroscopy (AAS), Inductively Coupled Plasma (ICP-Absorption/Emission) Spectroscopy and electrochemical sensing techniques are currently used for measuring $\mathrm{Cu}^{2+}$ concentration in solution in the nanomolar to micromole range [8]-[11]. These techniques are expensive to run and extremely tedious. Sample preparation process is complex and time-consuming. Moreover, it is challenging to reliably detect ultra-low concentration of $\mathrm{Cu}$ ions in the picomolar to sub-nanomolar range using these techniques in presence of other interfering ions and dissolved molecules. Fluorescence based sensing probes have the potential to address some of the above challenges. Because of high sensitivity of fluorescence technique, it should be possible to detect ultra-low concentration of $\mathrm{Cu}$ ions in solution. To minimize interference, it is possible to design $\mathrm{Cu}$ ion selective fluorescence probes. It is also possible to increase signal-to-noise ratio by designing activatable sensing probes. Since this is an optical based technique, fabrication of a field-deployable sensor device could be possible.

Several studies have reported detection of $\mathrm{Cu}^{2+}$ in micro molar concentration in biological systems using fluorescent dyes [12]-[25] and fluorescent proteins [26] [27]. Weida Wang et al. used a fluorescent dye (2,4,6trihydroxyphenylsquaraine) [20] as sensing probe to detect $\mathrm{Cu}$ ions. Despite a very complex synthesis strategy, cellular cytotoxicity was the primary limitation. In another study, 1,2,4-triazole was used as $\mathrm{Cu}$ ion sensing probe [28], however low stability of the probe was an issue. A similar probe based on Rhodamine dye tagged quinaldinet was developed by Zhang et al. [29]. This probe was able to detect $\mathrm{Cu}$ ions within about 10 - 15 minutes; however a large amount of the dye ( $\sim 5: 1$ dye to $\mathrm{Cu}$ ratio) was required for reliable measurements. Fluorescent proteins, red-emitting HcRed and green-emitting GFP, mutated to have $\mathrm{Cu}$ binding sites were shown to effectively recognize $\mathrm{Cu}$ ions in biological fluids [26] [27]. Upon binding to $100 \mu \mathrm{m} \mathrm{Cu}$ ions, almost $100 \%$ fluorescence quenching was observed. The drawback of this sensing strategy is associated with the stability of the proteins. HcRed was shown to perform better at low temperature [27]. Recently, a coumarin dye based fluorescence probe has been reported [30] that exhibits high selectivity towards $\mathrm{Cu}^{2+}$ ions. Fluorescence quenching is observed when $\mathrm{Cu}^{2+}$ ions bind to green-emitting (450 nm emission) coumarin dye derivative. The sensitivity of the detection was directly proportional to dye concentration. The probe works well in the $\mathrm{pH}$ range between 4 and 10 which is desired $\mathrm{pH}$ range for biological applications. When excess dye was used to boost the signal-tonoise ratio, self-quenching of the coumarin dye was observed dye to the formation of J-aggregation [30].

In this paper, we would propose to design synthetic scheme of coumarin conjugated Graphene Oxide (GO) nanomaterial. This design will take advantage of the high selectivity of the coumarin derivative towards $\mathrm{Cu}^{2+}$ ions as reported in the literature [30] and minimize the self-quenching problem. This is a feasible strategy as the coumarin dye will be covalently attached to GO surface and this attachment will hinder the formation of J-aggregation of coumarin dye molecules. The use of GO to prevent such J-aggregation has been reported in the 
literature [31] [32].

\subsection{Graphene-A 2D Robust Substrate Having Enormously Large Surface Area}

During the recent time Graphene, GO and nanomaterial research has gained a tremendous momentum because of their potential applications in material science [33] [34]. Graphene has a two-dimensional (one atom thick) crystals of $\mathrm{SP}^{2}$ bonded carbon atoms densely packed in a honey comb crystalline lattice. The C-C bond length of graphene is $0.142 \mathrm{~nm}$ and Graphene sheets are stuck to form graphite with inter planner spacing of $0.335 \mathrm{~nm}$. It possesses some unique properties such as high surface area $\left(2620 \mathrm{~m}^{2} / \mathrm{g}\right)$, high electronic conductivity (electron mobility 20,000 cm/second under unit potential gradient) low resistivity (specific resistance) $10^{-6} \mathrm{Oh}$-cm) high mechanical and chemical stability [35].

Calculation based on $a b$ initio shows that Graphene is thermodynamically unstable if it contains less than 6000 atoms (by Shenderovaab et al.) [36]. Graphene is a hydrophobic material and it has no binding sites available for ions. Graphene is chemically converted to GO (via oxidation)/GO derivatives for increasing its hydrophillicity by introducing suitable functional groups. GO can be dispersed in aqueous solution and they carry hydroxyls, acids and epoxy groups on the surface [37]. Functional groups on the GO surface can be further modified to attach suitable ligands [37]. In general, GO is considered as a biocompatible material. However, there are reports showing cytotoxic effect of GO to human fibroblast cells above $50 \mu \mathrm{g} / \mathrm{mL}$ concentration [38].

\section{Experimental Scheme}

\subsection{Synthetic Strategy}

The basic idea is to attach GO, a high surface area substrate material to the $\mathrm{Cu}$ ion selective fluorescent dye (such as coumarin, scheme shown in Figure 1). For such attachment, $\mathrm{Cu}$ ion selective coumarin dye derivative (as reported in the literature [30]; Figure 2) will be further modified to obtain a terminal primary amine group.

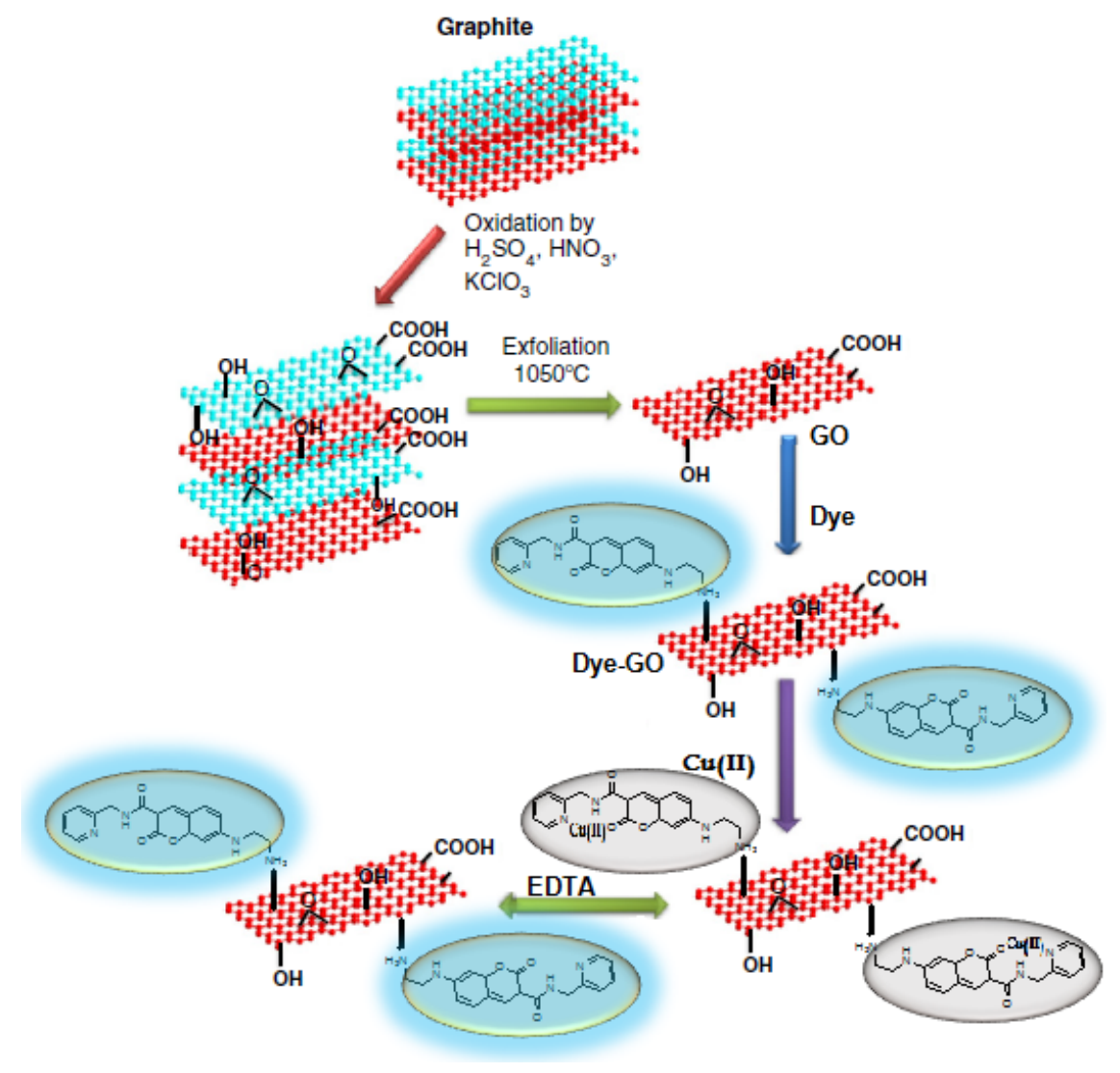

Figure 1. Pictorial representation of the scheme. 


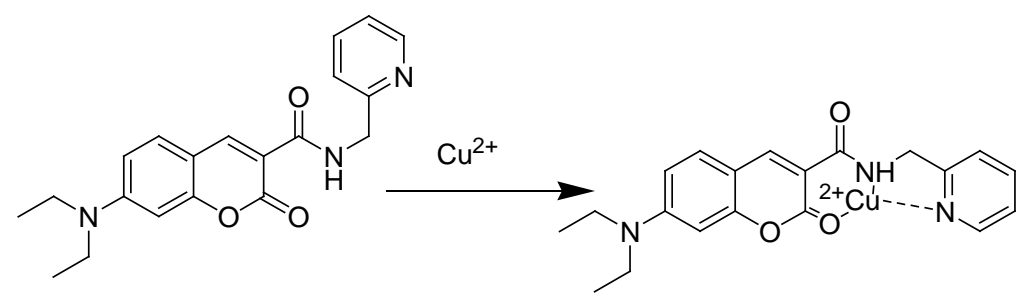

Figure 2. Schematic representation of the $\mathrm{Cu}^{2+}$ ion selective coumarin dye showing the active $\mathrm{Cu}^{2+}$ ion binding site.

The amine functionalized coumarin dye will be covalently attached to GO surface through epoxy ring opening reaction, forming the GOCD. Since the coumarin dye molecules are covalently attached to the GO substrate, it is anticipated that dye-dye interaction (J-aggregation) will be minimized. This is important for boosting the sensitivity for the $\mathrm{Cu}^{2+}$ ion detection in the nanomolar range. Moreover, the proposed GOCD is a new hybrid material. It would be interesting to explore the photophysical properties of the GOCD.

\subsection{Schematic Representation of Overall Synthetic Strategy}

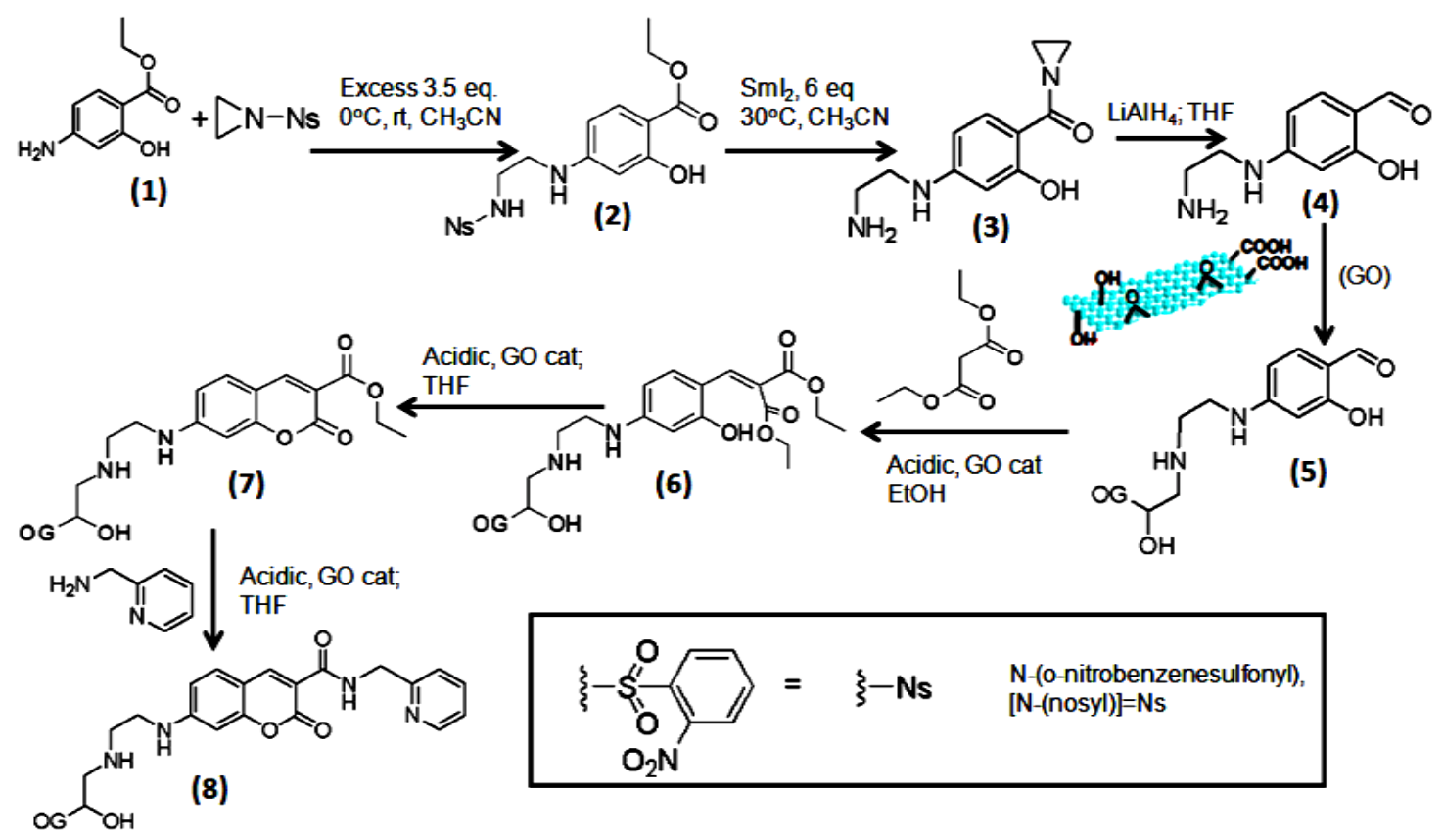

Figure 3. The proposed synthesis scheme of GOCD (compound \#8).

\subsection{Synthesis of Graphene-Oxide Coumarin Conjugate (GOCD)}

The proposed GOCD will involve a multi-step synthesis process.

Step 1 is the preparation of the GO from graphite flakes following Hummar [39] method. This method uses chemical and sonication techniques to exfoliate GO from purified natural graphite. The resulting exfoliated GO form colloidal suspension of individual GO sheet in water. Then following the procedure of Wang et al. [40], $\mathrm{pH}$ assisted selective sedimentation will be done to separate GO of different size range.

Step 2 is the synthesis of primary amine functionalized $\mathrm{Cu}^{2+}$ ion selective coumarin dye (compound \#4, see Figure 3). An amine containing precursor, methyl 4-amino-2-hydroxybenzoate (compound \#1, Sigma-Aldrich; catalogue \#PH001949) will be reacted with the protected az-ir-idine to make compound \#2. This addition reaction involves nucleophilic ring opening of az-ir-idine by the $\mathrm{NH}_{2}$ group of the compound \#1 under mild acidic reaction condition to control reaction rate. Compound \#3 (a cyclic ester) will be then prepared by treating the compound \#2 with acetonitrile in presence of $\mathrm{SmI}_{2}$ catalyst. Using $\mathrm{LiAlH}_{4}$, selective reduction reaction will be 
carried out to convert the compound \#3 to the corresponding aldehyde (compound \#4). Similar synthetic route has been reported in the literature where Diethylamino-2-hydroxy-benzaldehyde was used as the precursor starting material [30] instead of compound \#1 and therefore this proposed synthesis step is feasible.

Step 3 is the GO conjugation with the compound \#4 (Figure 3), forming compound \#5. The GO which is produced via Hammer method is intrinsically acidic and it has surface epoxy groups. It is expected that the compound \#4 will readily react with the epoxy containing GO when combined together. The terminal amine group of the compound $\# \mathbf{4}$ will take part in the epoxy ring opening reaction. Similar epoxy ring opening reactions involving primary amine containing molecules and the GO have been reported in the literature [37] [41] [42].

Step 4 is a simple acid catalyzed Michael type addition reaction between the dimethyl malonate and the compound \#5, forming the compound \#6. Then the compound \#6 will be converted to the compound \#7 in acidic condition where GO is expected to serve as a catalyst. This proposed synthesis step is based on a recent research reported by the Bielawski group [43]. Their findings confirmed that GO served as a catalyst in auto tandem oxidation-aldol condensation reaction [43]. Similar catalytic/carbocatalyst [44] activity is expected in the proposed condensation and hydride elimination step.

$\underline{\text { Step } 5}$ is the final step where the compound \#7 will be converted to the compound \#8 (the proposed GOCD). In this step, 2-aminomethyl pyridine addition and condensation reaction catalyzed by GO will be carried out in acidic reaction condition.

\section{Conclusion}

Synthetic steps proposed for synthesis of GOCD are conventional and uses of GO as catalyst are also well reported. Fluorescence of coumarin in GO-coumarin derivative (GOCD) will quench upon binding with $\mathrm{Cu}$ ions similar to its quenching of coumarin derivative as studied previously. Presence of GO in GOCD will not affect the strong fluorescence emission of coumarin derivative as GO is reported to exhibit a weak fluorescence property and it is covalently boded to CD. GOCD should exhibit two distinct absorption bands characteristic to GO (200 - $450 \mathrm{~nm}$ absorption) and the coumarin dye $(430 \mathrm{~nm})$. Based on the literature reports, it is evident that the absorption band position of GO largely depends a number of factors including particle size, $\mathrm{pH}$ and the degree of oxidation [45] [46]. GO usually emits in the range $400-700 \mathrm{~nm}$ [46]-[48]. Depending on the pH, GO particle size [45] and extent of GO oxidation, emission of GO could vary anywhere between the 370 - $650 \mathrm{~nm}$ [45] [46]. Since GO is water soluble, GOCD will also be water dispersible and minimize dye-dye aggregation. Thus, GOCD will be an ideal fluorescence sensor for estimation of nanomolar concentration of cupric ion in aqueous solutions and biological organs.

\section{Acknowledgements}

SBM is thankful to Dr. Swadeshmukul Santra of NSTC, UCF for his valuable suggestions and guidance.

\section{References}

[1] Richardson, H.W. (1997) Handbook of Copper Compounds and Applications. Marcel Dekker, Inc., New York, 1-432.

[2] Eisler, R. (1998) Copper Hazards to Fish, Wildlife, and Invertebrates: A Synoptic Review. Geological Survey, Washington DC.

[3] Forstner, U. and Wittmann, G.T.W. (1979) Metalpollution in the Aquatic Environment. Springer-Verlag, Berlin, 1-486. http://dx.doi.org/10.1007/978-3-642-96511-1_1

[4] Bowen, H.J.M. and Hutzinger, D. (1985) The Natural Environment and the Biogeochemical Cycles. The Handbook of Environmental Chemistry. Springer-Verlag, New York, 1-26. http://dx.doi.org/10.1007/978-3-540-39209-5_1

[5] Multhaup, G. (1997) Amyloid Precursor Protein, Copper and Alzheimer's Disease. Biomedicine Pharmacotherapy, 51, 105-111. http://dx.doi.org/10.1016/S0753-3322(97)86907-7

[6] Donnelly, P.S., Xiao, Z.G. and Wedd, A.G. (2007) Copper and Alzheimer's Disease. Current Opinion in Chemical Biology, 11, 128-133. http://dx.doi.org/10.1016/j.cbpa.2007.01.678

[7] Harris, Z.L. and Gitlin, J.D. (1996) Genetic and Molecular Basis for Copper Toxicity. American Journal of Clinical Nutrition, 63, 836-841.

[8] Cordeiro, C.R.B., Marques, A.L.B., Marques, E.P., Cardoso, W.S. and Zhang, J. (2006) Ultra Trace Copper Determi- 
nation by Catalytic-Adsorptive Stripping Voltammetry Using an Alizarin Red S Modified Graphite Electrode. International Journal of Electrochemical Science, 1, 343-353.

[9] Mulazimoglu, I.E. (2012) Electrochemical Determination of Copper(II) Ions at Naringenin-Modified Glassy Carbon Electrode: Application in Lake Water Sample. Desalination and Water Treatment, 44, 161-167. http://dx.doi.org/10.1080/19443994.2012.691692

[10] Minami, T., Sohrin, Y. and Ueda, J. (2005) Determination of Chromium, Copper and Lead in River Water by GraphiteFurnace Atomic Absorption Spectrometry after Coprecipitation with Terbium Hydroxide. Analytical Sciences, 21, 1519-1521. http://dx.doi.org/10.2116/analsci.21.1519

[11] Kalis, E.J.J., Weng, L., Dousma, F., Temminghoff, E.J.M. and Van Riemsdijk, W.H. (2006) Measuring Free Metal Ion Concentrations in Situ in Natural Waters Using the Donnan Membrane Technique. Environmental Science Technology, 40, 955-961. http://dx.doi.org/10.1021/es051435v

[12] Shao, N., Zhang, Y., Cheung, S.M., Yang, R.H., Chan, W.H., Mo, T., et al. (2005) Copper Ion-Selective Fluorescent Sensor Based on the Inner Filter Effect Using a Spiropyran Derivative. Analytical Chemistry, 77, 7294-7303. http://dx.doi.org/10.1021/ac051010r

[13] Sirilaksanapong, S., Sukwattanasinitt, M. and Rashatasakhon, P. (2012) 1,3,5-Triphenylbenzene Fluorophore as a Selective $\mathrm{Cu}^{2+}$ Sensor in Aqueous Media. Chemical Communications, 48, 293-295. http://dx.doi.org/10.1039/c1cc16148b

[14] Dong, Y., Koken, B., Ma, X., Wang, L., Cheng, Y. and Zhu, C. (2011) Polymer-Based Fluorescent Sensor Incorporating 2,2'-Bipyridyl and Benzo[2,1,3]Thiadiazole Moieties for $\mathrm{Cu}^{2+}$ Detection. Inorganic Chemistry Communications, 14, 1719-1722. http://dx.doi.org/10.1016/j.inoche.2011.07.014

[15] Frigoli, M., Ouadahi, K. and Larpent, C. (2009) A Cascade FRET-Mediated Ratiometric Sensor for $\mathrm{Cu}^{2+}$ Ions Based on Dual Fluorescent Ligand-Coated Polymer Nanoparticles. Chemistry—A European Journal, 15, 8319-8330. http://dx.doi.org/10.1002/chem.200900475

[16] Helal, A., Rashid, M.H.O., Choi, C.H. and Kim, H.S. (2011) Chromogenic and Fluorogenic Sensing of $\mathrm{Cu}^{2+} \mathrm{Based}$ on Coumarin. Tetrahedron, 67, 2794-2802. http://dx.doi.org/10.1016/j.tet.2011.01.093

[17] Zhou, Y., Wang, F., Kim, Y., Kim, S.J. and Yoon, J. (2009) $\mathrm{Cu}^{2+}$-Selective Ratiometric and “Off-On” Sensor Based on the Rhodamine Derivative Bearing Pyrene Group. Organic Letters, 11, 4442-4445. http://dx.doi.org/10.1021/ol901804n

[18] Zhao, X.H., Ma, Q.J., Zhang, X.B., Huang, B., Jiang, Q. and Zhang, J. (2010) A Highly Selective Fluorescent Sensor for $\mathrm{Cu}^{2+}$ Based on a Covalently Immobilized Naphthalimide Derivative. Analytical Sciences, 26, 585-590. http://dx.doi.org/10.2116/analsci.26.585

[19] Yin, S., Leen, V., Van, S.S., Boens, N. and Dehaen, W. (2010) A Highly Sensitive, Selective, Colorimetric and NearInfrared Fluorescent Turn-On Chemosensor for $\mathrm{Cu}^{2+}$ Based on BODIPY. Chemical Communications, 46, 6329-6331. http://dx.doi.org/10.1039/c0cc01772h

[20] Wang, W.D., Fu, A., You, J.S., Gao, G., Lan, J.B. and Chen, L.J. (2010) Squaraine-Based Colorimetric and Fluorescent Sensors for $\mathrm{Cu}^{2+}$-Specific Detection and Fluorescence Imaging in Living Cells. Tetrahedron, 66, 3695-3701. http://dx.doi.org/10.1016/j.tet.2010.03.070

[21] Li, G.K., Xu, Z.X., Chen, C.F. and Huang, Z.T. (2008) A Highly Efficient and Selective Turn-On Fluorescent Sensor for $\mathrm{Cu}^{2+}$ Ion Based on Calix 4 Arene Bearing Four Iminoquinoline Subunits on the Upper Rim. Chemical Communications, 2008, 1774-1776. http://dx.doi.org/10.1039/b800258d

[22] Jiao, L., Li, J., Zhang, S., Wei, C., Hao, E. and Vicente, M.G.H. (2009) A Selective Fluorescent Sensor for Imaging $\mathrm{Cu}^{2+}$ in Living Cells. New Journal of Chemistry, 33, 1888-1893. http://dx.doi.org/10.1039/b906441a

[23] Shamsipur, M., Poursaberi, T., Avanes, A. and Sharghi, H. (2006) Copper(II)-Selective Fluorimetric Bulk Optode Membrane Based on a 1-Hydroxy-9,10-Anthraquinone Derivative Having Two Propenyl Arms as a Neutral Fluorogenic Ionophore. Spectrochimica Acta Part A: Molecular and Biomolecular Spectroscopy, 63, 9-14.

[24] White, B.R. and Holcombe, J.A. (2007) Fluorescent Peptide Sensor for the Selective Detection of Cu ${ }^{2+}$. Talanta, 71, 2015-2020. http://dx.doi.org/10.1016/j.talanta.2006.09.009

[25] Mei, Y.J., Bentley, P.A. and Wang, W. (2006) A Selective and Sensitive Chemosensor for $\mathrm{Cu}^{2+}$ Based on 8-Hydroxyquinoline. Tetrahedron Letters, 47, 2447-2449. http://dx.doi.org/10.1016/j.tetlet.2006.01.091

[26] Ayyadurai, N., Prabhu, N.S., Deepankumar, K., Lee, S.G., Jeong, H.H., Lee, C.S. and Yun, H. (2011) Development of a Selective, Sensitive, and Reversible Biosensor by the Genetic Incorporation of a Metal-Binding Site into Green Fluorescent Protein. Angewandte Chemie, International Edition, 50, 6534-6537. http://dx.doi.org/10.1002/anie.201008289

[27] Rahimi, Y., Shrestha, S., Banerjee, T. and Deo, S.K. (2007) Copper Sensing Based on the Far-Red Fluorescent Protein, HcRed, from Heteractis crispa. Analytical Biochemistry, 370, 60-67. http://dx.doi.org/10.1016/j.ab.2007.05.018

[28] Huang, L., Chen, F., Xi, P., Xie, G., Li, Z., Shi, Y., et al. (2011) A Turn-On Fluorescent Chemosensor for Cu ${ }^{2+}$ in 
Aqueous Media and Its Application to Bioimaging. Dyes and Pigments, 90, 265-268. http://dx.doi.org/10.1016/j.dyepig.2011.01.003

[29] Zhang, J., Yu, C., Qian, S., Lu, G. and Chen, J. (2012) A Selective Fluorescent Chemosensor with 1,2,4-Triazole as Subunit for $\mathrm{Cu}(\mathrm{II})$ and Its Application in Imaging Cu(II) in Living Cells. Dyes and Pigments, 92, 1370-1375. http://dx.doi.org/10.1016/j.dyepig.2011.09.020

[30] Jung, H.S., Kwon, P.S., Lee, J.W., Kim, J.I., Hong, C.S., Kim, J.W., et al. (2009) Coumarin-Derived Cu ${ }^{2+}$-Selective Fluorescence Sensor: Synthesis, Mechanisms, and Applications in Living Cells. Journal of the American Chemical Society, 131, 2008-2012. http://dx.doi.org/10.1021/ja808611d

[31] Xu, Y., Malkovskiy, A. and Pang, Y. (2011) A Graphene Binding-Promoted Fluorescence Enhancement for Bovine Serum Albumin Recognition. Chemical Communications, 47, 6662-6664.

[32] Yavari, F., Chen, Z., Thomas, A.V., Ren, W., Cheng, H.M. and Koratkar, N. (2011) High Sensitivity Gas Detection Using a Macroscopic Three-Dimensional Graphene Foam Network. Scientific Reports, Article No. 166.

[33] Ahmadipour, M., Rao, K.V. and Rajandar, V. (2012) Formation of Nanoscale $\mathrm{Mg}_{(\mathrm{x})} \mathrm{Fe}_{(1-\mathrm{x})} \mathrm{O}(\mathrm{x}=0.1,0.2$, 0.4) Structure by Solution Combustion: Effect of Fuel to Oxidizer Ratio. Journal of Nanomaterials, 2012, Article ID: 163909. http://dx.doi.org/10.4236/anp.2012.13006

[34] Ahmadipour, M., Hatami, M. and Rao, K.V. (2012) Preparation and Characterization of Nano-Sized $\left(\mathrm{Mg}_{(\mathrm{x})} \mathrm{Fe}_{(1-\mathrm{x})} \mathrm{O} /\right.$ $\left.\mathrm{SiO}_{2}\right)(\mathrm{x}=0.1)$ Core-Shell Nanoparticles by Chemical Precipitation Method. Advance in Nanoparticles, 1, 37-43. http://dx.doi.org/10.1155/2012/163909

[35] Zhu, Y., Murali, S., Cai, W., Li, X., Suk, J.W., Potts, J.R. and Ruoff, R.S. (2010) Graphene and Graphene Oxide: Synthesis, Properties, and Applications. Advanced Materials, 22, 3906-3924. http://dx.doi.org/10.1002/adma.201001068

[36] Shenderovaab, O.A., Zhirnovac, V.V. and Brennera, D.W. (2002) Carbon Nanostructures. Critical Reviews in Solid State and Materials Sciences, 27, 227-356. http://dx.doi.org/10.1080/10408430208500497

[37] Dreyer, D.R., Park, S., Bielawski, C.W. and Ruoff, R.S. (2010) The Chemistry of Graphene Oxide. Chemical Society Reviews, 39, 228-240. http://dx.doi.org/10.1039/b917103g

[38] Wang, K., Ruan, J., Song, H., Zhang, J., Wo, Y. and Guo, S. (2011) Biocompatibility of Graphene Oxide. Nanoscale Research Letters, 6, 1-8.

[39] Hummers, W.S. and Offeman, R.E. (1958) Preparation of Graphitic Oxide. Journal of the American Chemical Society, 80, 1339-1339. http://dx.doi.org/10.1021/ja01539a017

[40] Wang, X., Bai, H. and Shi, G. (2011) Size Fractionation of Graphene Oxide Sheets by pH-Assisted Selective Sedimentation. Journal of the American Chemical Society, 133, 6338-6342. http://dx.doi.org/10.1021/ja200218y

[41] Wang, S., Lin, H.E., Lin, H.D., Chen, K.Y., Tu, K.H., Chen, C.W., et al. (2008) Transport Behavior and Negative Magnetoresistance in Chemically Reduced Graphene Oxide Nanofilms. Nanotechnology, 22, Article ID: 335701.

[42] Wang, S., Chia, P.J., Chua, L.L., Zhao, L.H., Png, R.Q., Sivaramakrishnan, S., et al. (2008) Band-Like Transport in Surface-Functionalized Highly Solution-Processable Graphene Nanosheets. Advanced Materials, 20, 3440-3446. http://dx.doi.org/10.1002/adma.200800279

[43] Jia, H.P., Dreyer, D.R. and Bielawski, C.W. (2011) Graphite Oxide as an Auto-Tandem Oxidation-Hydration-Aldol Coupling Catalyst. Advanced Synthesis \& Catalysis, 353, 528-532. http://dx.doi.org/10.1002/adsc.201000748

[44] Daniel, R.D., Hong, P.J. and Christopher, W.B. (2010) Graphene Oxide: A Convenient Carbocatalyst for Facilitating Oxidation and Hydration Reactions. Angewandte Chemie, International Edition, 49, 6813-6816.

[45] Galande, C., Mohite, A.D., Naumov, A.V., Gao, W., Ci, L., Ajayan, A., et al. (2011) Quasi-Molecular Fluorescence from Graphene Oxide. Scientific Reports, 1, Article No. 85.

[46] Eda, G., Lin, Y.Y., Mattevi, C., Yamaguchi, H., Chen, H.A., Chen, I.S., et al. (2010) Blue Photoluminescence from Chemically Derived Graphene Oxide. Advanced Materials, 22, 505-509. http://dx.doi.org/10.1002/adma.200901996

[47] Sun, X., Liu, Z., Welsher, K., Robinson, J.T., Goodwin, A., Zaric, S., et al. (2008) Nano-Graphene Oxide for Cellular Imaging and Drug Delivery. Nano Research, 1, 203-212. http://dx.doi.org/10.1007/s12274-008-8021-8

[48] Luo, Z., Vora, P.M., Mele, E.J., Johnson, A.T.C. and Kikkawa, J.M. (2009) Photoluminescence and Band Gap Modulation in Graphene Oxide. Applied Physics Letters, 94, Article ID: 111909. http://dx.doi.org/10.1063/1.3098358 
Scientific Research Publishing (SCIRP) is one of the largest Open Access journal publishers. It is currently publishing more than 200 open access, online, peer-reviewed journals covering a wide range of academic disciplines. SCIRP serves the worldwide academic communities and contributes to the progress and application of science with its publication.

Other selected journals from SCIRP are listed as below. Submit your manuscript to us via either submit@scirp.org or Online Submission Portal.
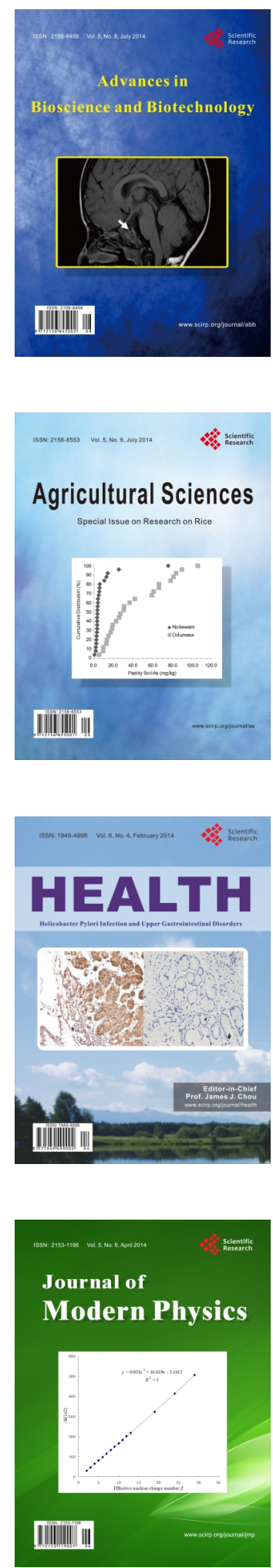
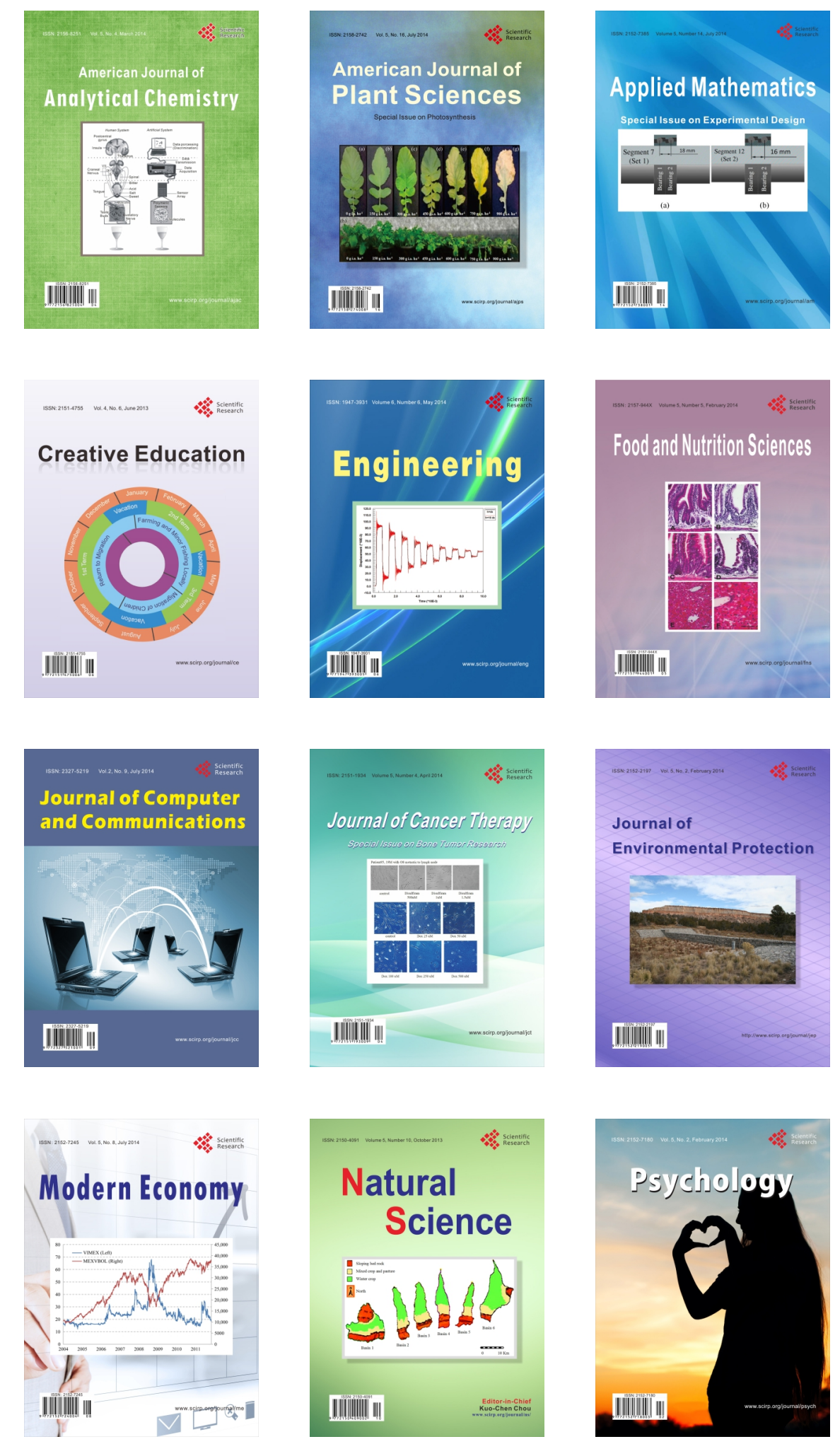